\title{
Waterlogging Tolerance of 57 Plant Species Grown Hydroponically
}

\author{
Ling Ma ${ }^{1}$
}

State Key Laboratory for Conservation and Utilization of Subtropical Agrobioresources, Guangdong Key Laboratory for Innovative Development and Utilization of Forest Plant Germplasm, Guangdong Province Research Center of Woody Forage Engineering Technology, College of Forestry and Landscape Architecture, South China Agricultural University, Guangzhou 510642, P.R. China; and the Department of Renewable Resources, University of Alberta, Edmonton, T6G 2E3, Alberta, Canada

\section{Xingquan Rao \\ South China Botanical Garden of Chinese Academy of Sciences, Guangzhou 510650, P.R. China}

\author{
Xiaoyang Chen ${ }^{1}$ \\ State Key Laboratory for Conservation and Utilization of Subtropical Agro- \\ bioresources, Guangdong Key Laboratory for Innovative Development and \\ Utilization of Forest Plant Germplasm, Guangdong Province Research \\ Center of Woody Forage Engineering Technology, College of Forestry and \\ Landscape Architecture, South China Agricultural University, Guangzhou \\ 510642, P.R. China
}

Additional index words. hydroponic experiment, ecological restoration, phenotype, provenance

\begin{abstract}
Plans for hydroponic experiments, as well as the flooding of watersheds for ecological restoration, require abundant evaluation information regarding plant species adapted to waterlogged environments. In this study, we observed the growth rate and phenotypes of 57 plant species, including nine provenances of four species grown hydroponically. The 57 species were from 22 families and 33 genera, and their waterlogging tolerance (WT) was classified into five categories according to the results of the evaluation: excellent, good, ordinary, poor, and very poor. We found that $60 \%$ of these plant species were able to survive in hydroculture for more than $\mathbf{1 0}$ weeks. They showed new shoot growth and had a survival rate of more than $60 \%$. Species with excellent or good WT developed new leaves rapidly under waterlogging stress, whereas species with ordinary or poor WT exhibited old leaves dropping from the stem soon after waterlogging stress. In addition, phenotypic divergence occurred among provenances of the same species under waterlogging stress.
\end{abstract}

With the increasing frequency and intensity of extreme weather events because of climate change, more frequent rainstorms occur in many areas where existing drainage systems cannot handle the excess. Thus, the

Received for publication 10 Jan. 2019. Accepted for publication $10 \mathrm{Jan} .2019$

This work was supported by the National Natural Science Foundation of China (grant no. 31600307), the Forestry Science and Technology Innovation Project from the Forestry Department of Guangdong Province (grant no. 2017KJCX033), and the Science and Technology Planning Project of Guangdong Province (grant nos. 2015A020209139 and 2015B020207002).

We thank Xiaomei Deng, Hao Huang, Boyong Liao, and Xiangbin Zhou for germinating seeds; Juncheng $\mathrm{Li}$ for technical assistance; Xinsheng $\mathrm{Hu}$ for language improvement; and Rongjing Zhang and Huiming Lian for their valuable information about growth rate of tree seedlings under natural conditions. ${ }^{1}$ Corresponding authors. E-mail: maling@scau.edu.cn or xychen@scau.edu.cn. lower areas frequently encounter the potential risk of flooding during the rainy season. In forest management, information regarding WT of plant species is necessary to cope with flooding. In addition, ecological restoration in depression areas or flooded watersheds must involve waterlogging-tolerant plant species. To investigate these effects under controlled plant growth conditions, homogenous components of growth nutrients in solution are necessary for plant physiology research, agricultural nutrition research, and even research under field conditions. A homogeneous nutrient solution is an ideal material for controlling experiments to explore the response of species to factors besides nutrition. Because of hypoxic stress, the growth of the same species differed in soil cultures and hydroculture, although the nutrition reagent was the same. Therefore, evaluation of plant species grown hydroponically can provide important reference information for flooding watershed ecological restoration, as well as for designing hydroponic experiments.
Hypoxic and anoxic conditions occur when the soil is water saturated, which induces various changes in physiology (Amador et al., 2012), morphology, anatomy, and other parameters (Guo et al., 2011; Kreuzwieser and Rennenberg, 2014). However, plants have evolved morphologically and physiologically to adapt to the flooding environment, including defoliation, and reduction in leaf number and size (Ye et al., 2003). For leaf characteristics, morphological adaptions varied among different ecotypes and different species.

In this study, we examined the growth rates and leaf phenotypes of 57 plant species with several different provenances grown hydroponically for more than 10 weeks. We hypothesized the following: 1) length of survival under waterlogging stress should be a criterion of primary importance for the screening of plant species for watershed ecosystem restoration and 2) phenotypic divergence will not occur among provenances of the same species under waterlogging stress. The goal of this study was to select species among the 57 plant species that could be used for flooding watershed ecological restoration.

\section{Materials and Methods}

Plant materials. All 57 plant species shown in Supplemental Table 1 are indigenous evergreen trees from Guangzhou City and are adapted to tropical or subtropical environments. Seedlings, age 12 to 15 months, were classified into group I. Seedlings age 6 to 11 months were classified into group II. Group I and group II seedlings were collected locally in Feb. 2014. Group III included those seedlings germinated from seeds in Nov. 2013. All seedlings were grown outdoors in a nursing bag (diameter, $8 \mathrm{~cm}$; depth, $12 \mathrm{~cm}$ ) containing soil with moderate watering before the treatment. In Mar. 2014, after the roots were cleaned thoroughly, seedlings with healthy foliage and sprouts were transplanted individually into plastic pots (diameter, 9.5 $\mathrm{cm}$; depth, $13.5 \mathrm{~cm}$ ) containing modified Hoagland solution ( $\mathrm{pH}=6.0$; Table 1$)$, such that only the roots were submerged thoroughly in the solution. Provenances of the four species, including Melia azedarach, Toona sinensis, Anthocephalus chinensis, and Mytilaria laosensis were obtained based on the available germplasm resources of our research team. Geographic and environmental information for each provenance are shown in Table 2. Fifty seedlings of each species or provenance were collected initially. During collection, seedlings of the same species or provenance were chosen based on uniformity of size. The modified Hoagland solution in each pot was renewed every $4 \mathrm{~d}$ to maintain stable nutrient supplies.

Hydroponic experiments were conducted in a well-ventilated glasshouse without shading from Mar. to May 2014. During the experiments, the indoor air temperature was 16 to $35^{\circ} \mathrm{C}$ and the air relative humidity was $60 \%$ to $98 \%$. 
Seedling growth rate under natural conditions. Seedling growth rate (SGR) was recorded for all groups based on changes in seedling height. Three levels were specified to mark the SGR for each species: Rapid, indicating the SGR was greater than $20 \mathrm{~cm} /$ month; Common, for which the SGR was between 10 and $20 \mathrm{~cm} /$ month; and Slow, for which the SGR was less than $10 \mathrm{~cm} /$ month.

Survival rate calculation. The survival of seedlings was documented every $2 \mathrm{~d}$. During the first week, the number of dead seedlings $\left(D_{1}\right)$ was recorded for each species. We attributed a $\mathrm{D}_{1}$ value less than three to root injury during cleaning. However, a $\mathrm{D}_{1}$ value greater than three indicated waterlogging stress.

The survival rate $\left(\mathrm{SR}_{1}\right)$ was calculated as follows:

$$
\mathrm{SR}_{1}=\frac{50-\mathrm{D}_{1}}{50} \times 100 \% .
$$

After 10 weeks, the number of dead seedlings $\left(D_{2}\right)$ was recorded again. To exclude those with root injuries caused by cleaning, the survival rate after 10 weeks $\left(\mathrm{SR}_{2}\right)$ was calculated as follows:

$$
\mathrm{SR}_{2}=\frac{50-\mathrm{D}_{1}-\mathrm{D}_{2}}{50-\mathrm{D}_{1}} \times 100 \%
$$

Phenotype assessment. The growth performance of all 57 species was assessed based on leaf growth status every $2 \mathrm{~d}$ during the experiment. Growth performance was grouped as follows: A, new leaves had expanded; B, leaves had wilted and dropped from the stem; C, seedlings had grown very slowly or had ceased growing; D, all leaves had dropped rapidly whereas the terminal bud remained alive, which meant that the stem, branch, and terminal bud had not withered until the end of the experi-

Table 1. Modified Hoagland nutrient solution

\begin{tabular}{|c|c|}
\hline Component & Concn $\left(\mathrm{mg} \cdot \mathrm{L}^{-1}\right)$ \\
\hline $\mathrm{Ca}\left(\mathrm{NO}_{3}\right)_{2} \cdot 4 \mathrm{H}_{2} \mathrm{O}$ & 472 \\
\hline $\mathrm{KNO}_{3}$ & 202 \\
\hline $\mathrm{NH}_{4} \mathrm{NO}_{3}$ & 80 \\
\hline $\mathrm{KH}_{2} \mathrm{PO}_{4}$ & 100 \\
\hline $\mathrm{K}_{2} \mathrm{SO}_{4}$ & 174 \\
\hline $\mathrm{MgSO}_{4} \cdot 7 \mathrm{H}_{2} \mathrm{O}$ & 246 \\
\hline $\mathrm{FeSO}_{4} \cdot 7 \mathrm{H}_{2} \mathrm{O}$ & 27.8 \\
\hline EDTA-2Na & 37.2 \\
\hline $\mathrm{H}_{3} \mathrm{BO}_{3}$ & 2.86 \\
\hline $\mathrm{MnSO} 4.4 \mathrm{H}_{2} \mathrm{O}$ & 2.13 \\
\hline $\mathrm{ZnSO}_{4} \cdot 7 \mathrm{H}_{2} \mathrm{O}$ & 0.22 \\
\hline $\mathrm{CuSO}_{4} \cdot 5 \mathrm{H}_{2} \mathrm{O}$ & 0.08 \\
\hline$\left(\mathrm{NH}_{4}\right)_{6} \mathrm{Mo}_{7} \mathrm{O}_{24} \cdot 4 \mathrm{H}_{2} \mathrm{O}$ & 0.02 \\
\hline
\end{tabular}
contents (Liu, 2004). ment; and E, the entire plant had withered rapidly.

The regeneration time for leaves for each species was divided into four periods: old leaves, coexisting old and new leaves, no leaves, and new leaves (Fig. 1). Each period was defined as follows: old leaves indicates that all fully expanded leaves existed when the experiment started; new leaves indicates that all leaves expanded fully after the experiment start date; coexisting old and new leaves indicates that at least one old leaf and one new leaf coexisted; and no leaves indicates that no fully expanded leaves existed. Figure 1 lists the species in the same order as in Supplemental Table 1.

Fresh biomass growth rate calculation. Five seedlings in pots with $500 \mathrm{~mL}$ modified Hoagland solution were weighed at the end of the first week ( $\mathrm{W}_{1}$, measured in grams). Those that survived were weighed individually 10 weeks later ( $\mathrm{W}_{2}$, measured in grams). The fresh biomass growth rate (FBGR, measured as a percentage) was calculated as follows:

$$
\mathrm{FBGR}=\frac{\mathrm{W}_{2}-\mathrm{W}_{1}}{\mathrm{~W}_{1}} \times 100 .
$$

However, for some species, the number of survivors among the individuals that had been weighed for $\mathrm{W}_{1}$ was less than three for the $\mathrm{W}_{2}$ data. In such cases, we weighed other surviving seedlings instead, and we set the mean value of $\mathrm{W}_{1}$ of the five seedlings weighed as the alternate value for $\mathrm{W}_{1}$.

WT class. We evaluated and ranked WT of the 57 species, as well as the provenances based on $\mathrm{SR}_{2}$, phenotype, FBGR (mean value), and SGR according to Eq. 4. The metrics and weight values for Eq. 4 are shown in Table 3 .

$$
\begin{aligned}
\mathrm{WT}= & a \times \mathrm{SR}_{2}+b \times \mathrm{phy}+c \\
& \times \mathrm{FBGR}-d \times \mathrm{SGR},
\end{aligned}
$$

where $a, b, c$, and $d$ are the weighting factors assigned according to the impact of each parameter on WT; and phy is phenotype. In this study, we assumed that the weight for $\mathrm{SR}_{2}$, phenotype, FBGR, and SGR would be $80 \%, 20 \%, 20 \%$, and $10 \%$, respectively. Nevertheless, in consideration of the differences between the ranges of values for each parameter, which influence the effect of the assigned weight value, we adjusted each weight value by dividing by the maximum value of each parameter (rounded to an integer). Thus, the values of $a, b, c$, and $d$ were $0.8,0.133,0.067$, and 0.033 , respectively. Furthermore, the value of a hybrid phenotype was determined using the product of each assigned phenotype value. For example, the value of phenotype $\mathrm{ABC}$ was 0.6 , which was obtained by the product of 1.5 , 0.8 , and 0.5 .

The WT class of the 57 plant species with nine provenances was determined as follows: Excellent, WT $\geq 0.95$; Good, WT $<0.95$ but $\geq 0.8$; Ordinary, WT $<0.8$ but $\geq 0.4$; Poor, WT $<0.4$; and Very Poor, those species with phenotype E, which therefore lacked a WT value.

\section{Results}

Survival rate. In this study, the $\mathrm{D}_{1}$ values of 22 species were less than three. The $\mathrm{SR}_{2}$ values of nine species were greater than $95 \%$. Of these, Dalbergia odorifera (no. 1), Ficus concinna (no. 2), Canavalia ensiformis (no. 3), Jatropha curcas (no. 4), Acacia auriculiformis (no. 5), and Ficus altissima (no. 6) had $\mathrm{SR}_{2}$ values of $100 \%$. Ten species (with different provenances) had $\mathrm{SR}_{2}$ values that ranged from $85 \%$ to $95 \%$. Sixteen species had $\mathrm{SR}_{2}$ values between $60 \%$ and $85 \%, 24$ species (with different provenances) had $\mathrm{SR}_{2}$ values less than $60 \%$, and the last three species-Zenia insignis (no. 60), Castanopsis fissa (no. 61), and Magnoliaceae glance (no. 62) - had $\mathrm{SR}_{2}$ values of zero (Supplemental Table 1). In total, $60 \%$ of the plant species were able to survive in the hydroculture for more than 10 weeks, exhibiting new shoot growth and a survival rate greater than $60 \%$.

Phenotypes. Phenotypes were assessed based on living individuals, except for those species that died rapidly, including $Z$. insignis (no. 60), C. fissa (no. 61), and M. glanca (no. 62). Overall, from high to low, $32 \%$ of the species exhibited phenotypes of $\mathrm{A}, \mathrm{B}$, and $\mathrm{C}$ combined; $31 \%$ were $\mathrm{A} ; 16 \%$ were $\mathrm{A}$ and $\mathrm{B}$ combined; followed by $8 \%, 5 \%, 3 \%, 3 \%, 2 \%$, and $0 \%$ for $\mathrm{A}$ and $\mathrm{D}$ combined, $\mathrm{E}$ alone, $\mathrm{B}$ and $\mathrm{C}$ combined, $\mathrm{D}$ alone, $\mathrm{A}$ and $\mathrm{C}$ combined, and B alone, respectively (Fig. 3).

Figure 1, which shows regeneration time of leaves for each species, illustrates the information regarding phenotypes. It shows that the species listed in the top part of Supplemental Table 1 had an old-leaves period only and a coexisting old- and newleaves period, whereas the species listed in

\begin{tabular}{|c|c|c|c|c|c|c|}
\hline Provenance & Geographic location & Latitude $(\mathrm{N})$ & Longitude (E) & Elevation (m) & $\begin{array}{c}\text { Mean annual } \\
\text { temp }\left({ }^{\circ} \mathrm{C}\right)\end{array}$ & $\begin{array}{c}\text { Mean annual } \\
\text { precipitation }(\mathrm{mm})\end{array}$ \\
\hline$\overline{\text { Melia azedarach }}{ }^{1}$ & Conghua, Guangdong, China & $23^{\circ} 33^{\prime}$ & $113^{\circ} 35^{\prime}$ & 35 & 21.5 & 1,670 \\
\hline Melia azedarach ${ }^{2}$ & Xingyi, Guizhou, China & $25^{\circ} 04^{\prime}$ & $104^{\circ} 40^{\prime}$ & 1,217 & 16.8 & 1,512 \\
\hline Toona sinensis ${ }^{1}$ & Lechang, Guangdong, China & $25^{\circ} 12^{\prime}$ & $113^{\circ} 33^{\prime}$ & 98 & 19.6 & 1,522 \\
\hline Toona sinensis ${ }^{2}$ & Malipo, Yunnan, China & $23^{\circ} 12^{\prime}$ & $104^{\circ} 70^{\prime}$ & 1,057 & 18 & 1,054 \\
\hline Anthocephalus chinensis ${ }^{1}$ & Guangzhou, Guangdong, China & $23^{\circ} 10^{\prime}$ & $113^{\circ} 21^{\prime}$ & 10 & 22.1 & 1,697 \\
\hline Anthocephalus chinensis ${ }^{2}$ & Jinghong, Yunnan, China & $21^{\circ} 03^{\prime}$ & $101^{\circ} 04^{\prime}$ & 553 & 21 & 1,197 \\
\hline Anthocephalus chinensis ${ }^{3}$ & Nanning, Guangxi, China & $22^{\circ} 85^{\prime}$ & $108^{\circ} 40^{\prime}$ & 80 & 21.7 & 1,304 \\
\hline Mytilaria laosensis ${ }^{1}$ & Shangsi, Guangxi, China & $21^{\circ} 53^{\prime}$ & $107^{\circ} 54^{\prime}$ & 412 & 21.5 & 1,218 \\
\hline Mytilaria laosensis ${ }^{2}$ & Ruyuan, Guangdong, China & $24^{\circ} 57^{\prime}$ & $113^{\circ} 26^{\prime}$ & 84 & 16 & 2,800 \\
\hline
\end{tabular}
the bottom part of Supplemental Table 1 had a short coexisting old- and new-leaves period, but a long new-leaves period.

Table 2. Geographic and environment information for provenances.

Superscript numbers $(1,2$, and 3$)$ after species names represent different provenances of same species. 
Old leaves period No leaves period

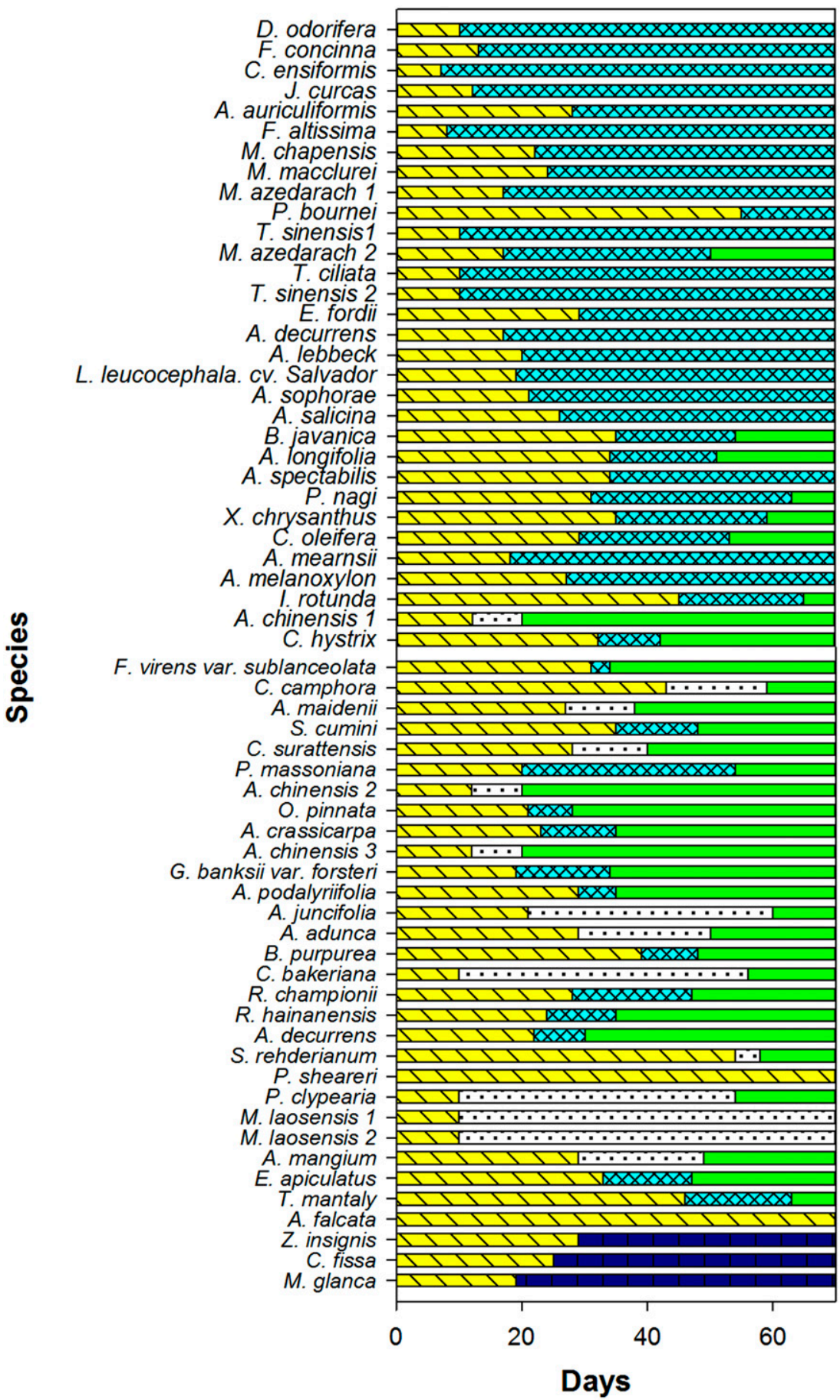

Fig. 1. Regeneration time of leaves. The old-leaves period indicates that all fully expanded leaves existed when the experiment started. The new-leaves period indicates that all leaves expanded fully after the experiment start date. The coexisting old- and new-leaves periods indicate that at least one old leaf and one new leaf coexisted. The no-leaf period indicates that no fully expanded leaves exist.

Fresh biomass growth rate. Species such as D. odorifera (no. 1), with common SGR, exhibited an FBGR of $\approx 150 \%$, demonstrating excellent adaptation to hydroculture. Younger seedlings, such as those of $C$. ensiformis (no. 3) and J. curcas (no. 4), which are classified as III in Supplemental Table 1, showed a greater FBGR, indicating they adapted well to hydroculture because of their rapid SGR and, to some extent, to a relatively low $\mathrm{W}_{1}$. However, some species, such as $P$. clypearia (no. 53), M. laosensis (nos. 54 and 55), A. mangium (no. 56), Elaeocarpus apiculatus (no. 57), Terminalia mantaly (no. 58), and $A$. falcata (no. 59), exhibited a negative FBGR (Supplemental Table 1), which resulted from leaf loss that exceeded new shoot growth.

In addition, species from different provenances-such as Melia azedarach ${ }^{1}$ (no. 9) and M. azedarach (no. 12); Toona sinensis $^{1}$ (no. 11) and T. sinensis ${ }^{2}$ (no. 14); M. laosensis $^{1}$ (no. 54) and M. laosensis ${ }^{2}$ (no 55); and $A$. chinensis ${ }^{1}$ (no. 30), A. chinensis ${ }^{2}$ (no. 38), and $A$. chinensis $^{3}$ (no. 41)-exhibited little variation in $\mathrm{SR}_{2}$ and $\mathrm{FBGR}$, and phenotypes among provenances were similar (Fig. 2, Supplemental Table 1).

WT rating. In this study, six species with $100 \% \mathrm{SR}_{2}$ were ranked Excellent, including $D$. odorifera (no. 1), F. concinna (no. 2), C. ensiformis (no. 3), J. curcas (no. 4), $A$. auriculiformis (no. 5), and F. altissima (no. 6). Twelve species, including two with four provenances, were ranked Good. Nineteen species, including one with two provenances, were ranked Ordinary; and 18 species, two of which had three provenances, were ranked Poor. Three species were ranked Very Poor: Z. insignis (no. 60), C. fissa (no. 61), and M. glanca (no. 62) (Fig. 2).

\section{Discussion}

After being grown hydroponically for 10 weeks, the survival rates of 27 species were greater than $60 \%$. However, a number of species did not grow well under waterlogging conditions. This result is consistent with our first hypothesis, that the length of survival under waterlogging stress should be a criterion of primary importance for screening plant species for watershed ecosystem restoration.

Synthesizing the information from Fig. 1 and Supplemental Table 1, we see that species with excellent or good WT soon developed new leaves under waterlogging stress, and old leaves remained alive, whereas species with ordinary or poor WT soon dropped old leaves from the stem under waterlogging stress, although some of them developed new leaves. This indicates that plant species with poor tolerance dropped leaves almost immediately when suffering from waterlogging stress, whereas those species with good WT developed new leaves soon after encountering waterlogging conditions, and dropped fewer old leaves.

Variation in phenotype is related closely to physiological responses under waterlogging. When waterlogged roots become hypoxic, normal cell metabolism is restricted and the physiological activities of aboveground organs are affected accordingly (Kreuzwieser and Rennenberg, 2014). Changes in phenotype occur over time. For example, some plants exhibited leaves that wilted and dropped from the stem under waterlogging, which may be correlated with changes in endogenous abscisic acid, indole acetic acid, gibberellic acid, nitric oxide, and ethylene, among other compounds (Bailey-Serres et al., 2012; Herrera, 2013; Pagnussat et al., 2004) or their ratios (Kim et al., 2015). The effects of endogenous hormones on phenotype under waterlogging vary by genotype and ecotype (Gomathi et al., 
Table 3. Metrics and weight values in the determination of waterlogging tolerance class.

\begin{tabular}{lccccc}
\hline Parameter & Abbreviation & $\begin{array}{c}\text { Weighting } \\
\text { factor }\end{array}$ & Wt value & Value or rank & Assigned value \\
$\begin{array}{l}\text { Survival rate after } \\
\quad \text { 10 weeks }\end{array}$ & $\mathrm{SR}_{2}$ & $\mathrm{a}$ & 0.800 & Calculated & N/A \\
Phenotype & phy & $\mathrm{b}$ & 0.133 & $\mathrm{~A}$ & \\
& & & & $\mathrm{~B}$ & 1.5 \\
& & & & $\mathrm{C}$ & 0.8 \\
& & & & $\mathrm{D}$ & 0.5 \\
& & & & $\mathrm{E}$ & 0.5 \\
Fresh biomass growth rate & FBGR & $\mathrm{c}$ & 0.067 & Calculated & 0 \\
Seedling growth rate & SGR & $\mathrm{d}$ & 0.033 & Rapid & 3 \\
& & & & Common & 2 \\
& & & & Slow & 1 \\
\hline
\end{tabular}

Lower case letters ( $\mathrm{a}, \mathrm{b}, \mathrm{c}$, and d) are weighting factors for $\mathrm{SR}_{2}$, phy, FBGR, and SGR, respectively. Their values are shown as $\mathrm{W}_{\mathrm{t}}$ value. Upper case letters $(\mathrm{A}, \mathrm{B}, \mathrm{C}, \mathrm{D}$, and $\mathrm{E}$ ) are rank marks for phenotype, while Rapid, Common, and Slow are rank marks for SGR.

$\mathrm{N} / \mathrm{A}=$ not applicable.

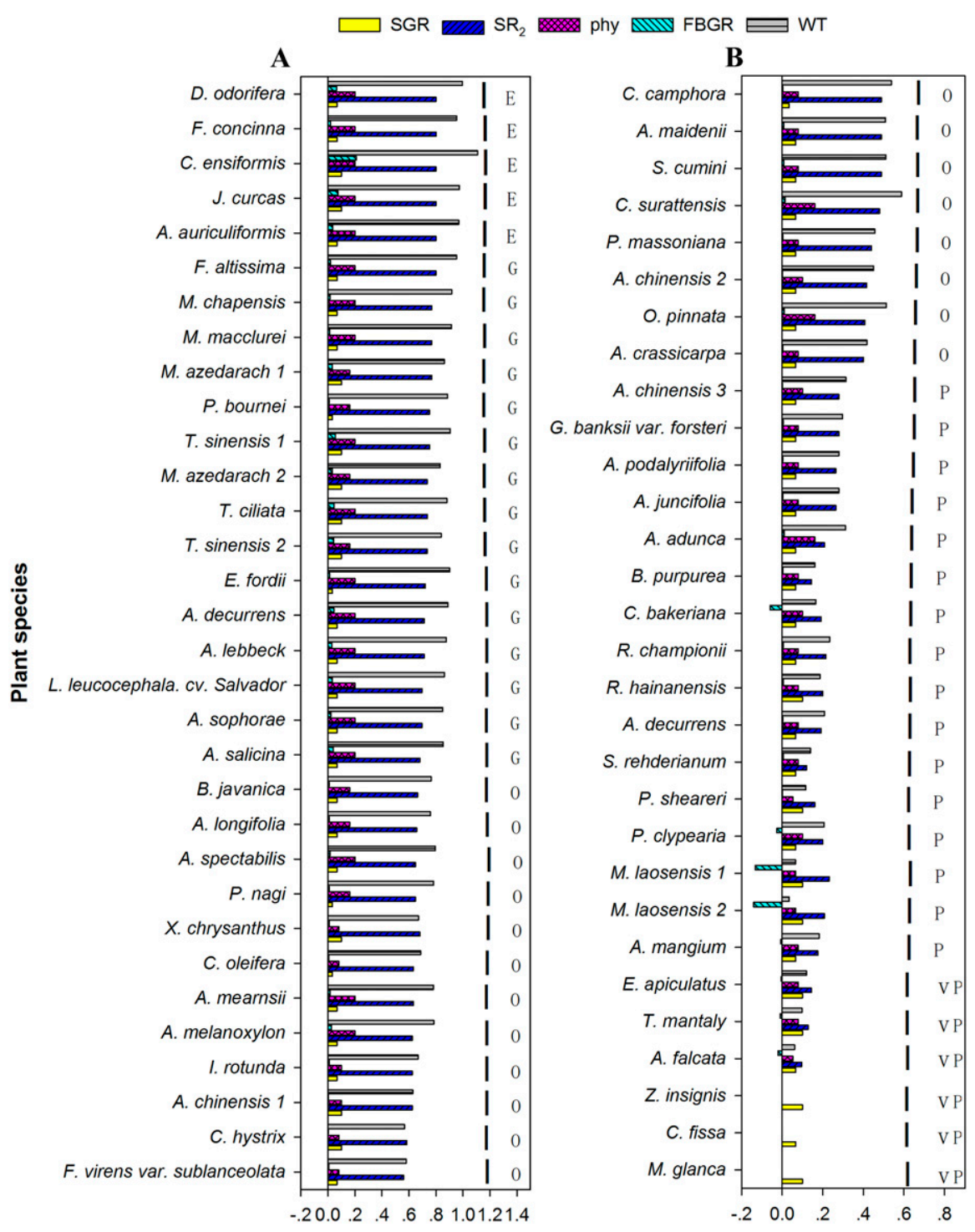

Fig. 2. Quantized and weighted seedling growth rate (SGR) under natural conditions, survival rate after 10 weeks $\left(\mathrm{SR}_{2}\right)$, phenotypes (phy), fresh biomass growth rate (FBGR), and waterlogging tolerance (WT) of 57 plant species in hydroculture [shown in two graphs (A and $\mathbf{B})$ and in the same order as in Supplemental Table 1]. The letters on the right of the bars indicate the WT class of each species: E, excellent; G, good; O, ordinary; P, poor; VP, very poor.

2015; Guo et al., 2011; Jaeger et al., 2009). In the current study, A. chinensis, C. bakeriana, P. clypearia, and M. laosensis were completely defoliated under waterlogging, after which
A. chinensis gradually grew new leaves, but the other species remained leafless. Overall, the mechanisms of endogenous hormone regulation of defoliation and growth under water-

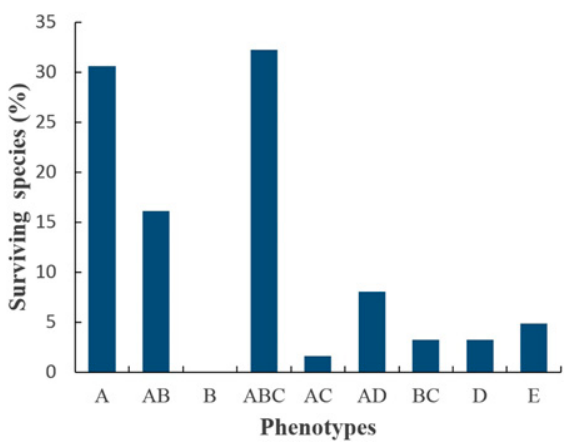

Fig. 3. Frequency distribution of phenotypes of surviving species. A, new shoots grew; B, leaves wilted and dropped from the stem; C, growth slowed or ceased; $\mathrm{D}$, all leaves withered or dropped rapidly, with the terminal bud remaining alive; E, the entire plant withered rapidly.

logging have not been fully revealed, and further exploration is needed.

Under waterlogging conditions, additional stress can arise because hypoxia or anoxia in the rhizosphere can induce the accumulation of large quantities of reactive oxygen species in roots and aboveground organs. This condition leads to saturation of the active oxygen scavenging system, resulting in increased peroxidation of membrane lipids, soluble sugars, and soluble proteins, as well as increased malondialdehyde production (Irfan et al., 2010). Chlorophyll breakdown also increases (Ye et al., 2003), and photosynthesis is restricted (Visser et al., 2003), inducing rapid death in some intolerant species, such as $Z$. insignis, M. glance, and C. fissa, according to our study.

Differences in abiotic stress tolerance among provenances of the same species from different climatic zones have been observed (Carsjens et al., 2014; Du et al., 2016; Yildiz et al., 2014), which is contrary to our second hypothesis that phenotypic divergence would not occur among provenances of the same species under waterlogging stress. This variability may be caused by differences among habitats and the duration of provenance separation. In our study, little variation in WT was found for $M$. azedarach, $T$. sinensis, M. laosensis, and $A$. chinensis provenances, although their WT did not exhibit the same trends as precipitation in their location of origin (Table 2). We presumed that WT is, to a large extent, determined by DNA, not the habitat for the species investigated in this study.

Adult trees have been found to be more tolerant to waterlogging than seedlings of the same species (Kreuzwieser and Rennenberg, 2014), and growth conditions of plants in hydroculture differ in certain aspects from those under waterlogging conditions in natural soil because of the vast differences in microelements and microbial communities. In addition, some plant species formed aerenchyma to cope with hypoxia under waterlogging, and thus maintained biomass production (Laan et al., 1991). In our study, Dalbergia odorifera, Ficus concinna, Canavalia ensiformis, Jatropha carcass, 
Acacia auriculiformis, and Ficus altissima exhibited new leaf growth and maintained high biomass production. We speculate that these species might form aerenchyma in hydroculture and should be suitable for use in ecological restoration of flooded watersheds in tropical or subtropical areas.

Taken together, our results indicate that some plant species cannot survive under hydroponic conditions. Evaluation of WT is essential before selecting species for use in hydroponic experiments or in flooding watershed restoration.

\section{Literature Cited}

Amador, M.L., S. Sancho, B. Bielsa, J. GomezAparisi, and M.J. Rubio-Cabetas. 2012. Physiological and biochemical parameters controlling waterlogging stress tolerance in Prunus before and after drainage. Physiol. Plant. 144:357-368.

Bailey-Serres, J., S. Cho Lee, and E. Brinton. 2012. Waterproofing crops: Effective flooding survival strategies. Plant Physiol. 160:1698-1709.

Carsjens, C., Q.N. Ngoc, J. Guzy, F. Knutzen, I.C. Meier, M. Muller, R. Finkeldey, C. Leuschner, and A. Polle. 2014. Intra-specific variations in expression of stress-related genes in beech progenies are stronger than drought-induced responses. Tree Physiol. 34:1348-1361.
Du, B.G., K. Jansen, A. Kleiber, M. Eiblmeier, B. Kammerer, I. Ensminger, A. Gessler, $\mathrm{H}$. Rennenberg, and J. Kreuzwieser. 2016. A coastal and an interior Douglas fir provenance exhibit different metabolic strategies to deal with drought stress. Tree Physiol. 36:148-163.

Gomathi, R., P.N. Gururaja Rao, K. Chandran, and A. Selvi. 2015. Adaptive responses of sugarcane to waterlogging stress: An overview. Sugar Tech. 17:325-338.

Guo, X.Y., Z.Y. Huang, A.C. Xu, and X.S. Zhang. 2011. A comparison of physiological, morphological and growth responses of 13 hybrid poplar clones to flooding. Forestry 84:1-12.

Herrera, A. 2013. Responses to flooding of plant water relations and leaf gas exchange in tropical tolerant trees of a black-water wetland. Front. Plant Sci. 4:106.

Irfan, M., S. Hayat, Q. Hayat, S. Afroz, and A. Ahmad. 2010. Physiological and biochemical changes in plants under waterlogging. Protoplasma 241:3-17.

Jaeger, C., A. Gessler, S. Biller, H. Rennenberg, and J. Kreuzwieser. 2009. Differences in C metabolism of ash species and provenances as a consequence of root oxygen deprivation by waterlogging. J. Exp. Bot. 60:4335-4345.

Kim, Y.H., S.J. Hwang, M. Waqas, A.L. Khan, J.H. Lee, J.D. Lee, H.T. Nguyen, and I.J. Lee. 2015. Comparative analysis of endogenous hormones level in two soybean (Glycine max L.) lines differing in waterlogging tolerance. Front Plant Sci. 6:714.
Kreuzwieser, J. and H. Rennenberg. 2014. Molecular and physiological responses of trees to waterlogging stress. Plant Cell Environ. 37:2245-2259.

Laan, P., J.M.A.M. Clement, and C.W.P.M. Blom. 1991. Growth and development of Rumex roots as affected by hypoxic and anoxic conditions. Plant Soil 136(2):145-151.

Liu, S.Z. 2004. Modern practical soilless culture techniques. China Agriculture Press, Beijing, P.R. China.

Pagnussat, G.C., M.L. Lanteri, M.C. Lombardo, and L. Lamattina. 2004. Nitric oxide mediates the indole acetic acid induction activation of a mitogen-activated protein kinase cascade involved in adventitious root development. Plant Physiol. 135:279-286.

Visser, E.J.W., L.A.C.J. Voesenek, B.B. Vartapetian, and M.B. Jackson. 2003. Flooding and plant growth. Ann. Bot. 91:107-109.

Ye, Y., N.F.Y. Tam, Y.S. Wong, and C.Y. Lu. 2003. Growth and physiological responses of two mangrove species (Bruguiera gymnorrhiza and Kandelia candel) to waterlogging. Environ. Exp. Bot. 49:209-221.

Yildiz, D., P. Nzokou, A. Deligoz, I. Koc, and M. Genc. 2014. Chemical and physiological responses of four Turkish red pine (Pinus brutia Ten.) provenances to cold temperature treatments. Eur. J. For. Res. 133:809818. 


\begin{tabular}{|c|c|c|c|c|c|c|c|}
\hline \multirow[b]{2}{*}{ No. } & \multirow[b]{2}{*}{ Name of species } & \multirow[b]{2}{*}{$\mathrm{SC}^{\mathrm{z}}$} & \multirow[b]{2}{*}{ SGR } & \multicolumn{2}{|c|}{ Survival rate $(\%)$} & \multirow[b]{2}{*}{ Phenotypes $^{\mathrm{y}}$} & \multirow[b]{2}{*}{ FBGR $(\%)$} \\
\hline & & & & $\mathrm{SR}_{1}$ & $\mathrm{SR}_{2}$ & & \\
\hline 1 & Dalbergia odorifera & I & Common & 98 & 100 & $\mathrm{~A}$ & $95 \pm 15$ \\
\hline 2 & Ficus concinna & $\mathrm{I}$ & Common & 100 & 100 & A & $31 \pm 5$ \\
\hline 3 & Canavalia ensiformis & III & Rapid & 100 & 100 & A & $313 \pm 54$ \\
\hline 4 & Jatropha curcas & III & Rapid & 100 & 100 & A & $109 \pm 18$ \\
\hline 5 & Acacia auriculiformis & $\mathrm{I}$ & Common & 100 & 100 & A & $53 \pm 8$ \\
\hline 6 & Ficus altissima & $\mathrm{I}$ & Common & 100 & 100 & A & $28 \pm 7$ \\
\hline 7 & Michelia chapensis & $\mathrm{I}$ & Common & 98 & 96 & A & $22 \pm 4$ \\
\hline 8 & Michelia macclurei & $\mathrm{I}$ & Common & 96 & 96 & A & $20 \pm 2$ \\
\hline 9 & Melia azedarach ${ }^{1}$ & II & Rapid & 100 & 96 & $\mathrm{AB}$ & $50 \pm 4$ \\
\hline 10 & Phoebe bournei & $\mathrm{I}$ & Slow & 98 & 94 & $\mathrm{AB}$ & $11 \pm 3$ \\
\hline 11 & Toona sinensis ${ }^{1}$ & II & Rapid & 100 & 94 & $\mathrm{~A}$ & $80 \pm 7$ \\
\hline 12 & Melia azedarach ${ }^{2}$ & II & Rapid & 100 & 92 & $\mathrm{AB}$ & $50 \pm 5$ \\
\hline 13 & Toona ciliata & II & Rapid & 98 & 92 & $\mathrm{~A}$ & $68 \pm 7$ \\
\hline 14 & Toona sinensis ${ }^{2}$ & II & Rapid & 100 & 92 & $\mathrm{AB}$ & $63 \pm 5$ \\
\hline 15 & Erythrophleum fordii & $\mathrm{I}$ & Slow & 96 & 90 & $\mathrm{~A}$ & $20 \pm 6$ \\
\hline 16 & Acacia decurrens & II & Common & 90 & 89 & A & $65 \pm 17$ \\
\hline 17 & Albizia lebbeck & II & Common & 90 & 89 & A & $45 \pm 25$ \\
\hline 18 & Leucaena leucocephala cv. Salvador & II & Common & 92 & 87 & A & $50 \pm 8$ \\
\hline 19 & Acacia sophorae & II & Common & 92 & 87 & A & $32 \pm 4$ \\
\hline 20 & Acacia salicina & II & Common & 90 & 85 & A & $60 \pm 16$ \\
\hline 21 & Bischofia javanica & I & Common & 94 & 83 & $\mathrm{AB}$ & $11 \pm 3$ \\
\hline 22 & Acacia longifolia & II & Common & 88 & 82 & $\mathrm{AB}$ & $12 \pm 2$ \\
\hline 23 & Acacia spectabilis & II & Common & 86 & 81 & A & $21 \pm 8$ \\
\hline 24 & Podocarpus nagi & $\mathrm{I}$ & Slow & 96 & 81 & $\mathrm{AB}$ & $11 \pm 3$ \\
\hline 25 & Xanthostemon chrysanthus & $\mathrm{I}$ & Rapid & 94 & 85 & $\mathrm{ABC}$ & $16 \pm 9$ \\
\hline 26 & Camellia oleifera & $\mathrm{I}$ & Slow & 84 & 79 & $\mathrm{ABC}$ & $10 \pm 6$ \\
\hline 27 & Acacia mearnsii & II & Common & 86 & 79 & A & $25 \pm 3$ \\
\hline 28 & Acacia melanoxylon & II & Common & 92 & 78 & A & $39 \pm 3$ \\
\hline 29 & Ilex rotunda & $\mathrm{I}$ & Common & 92 & 78 & $\mathrm{AC}$ & $14 \pm 1$ \\
\hline 30 & Anthocephalus chinensis ${ }^{1}$ & II & Rapid & 90 & 78 & $\mathrm{AD}$ & $5 \pm 3$ \\
\hline 31 & Castanopsis hystrix & $\mathrm{I}$ & Slow & 96 & 73 & $\mathrm{ABC}$ & $3 \pm 1$ \\
\hline 32 & Ficus virens var. sublanceolata & $\mathrm{I}$ & Common & 100 & 70 & $\mathrm{ABC}$ & $9 \pm 4$ \\
\hline 33 & Cinnamomum camphora & $\mathrm{I}$ & Slow & 98 & 61 & $\mathrm{ABC}$ & $5 \pm 1$ \\
\hline 34 & Acacia maidenii & II & Common & 98 & 61 & $\mathrm{ABC}$ & $12 \pm 2$ \\
\hline 35 & Syzygium cumini & I & Common & 98 & 61 & $\mathrm{ABC}$ & $13 \pm 7$ \\
\hline 36 & Cassia surattensis & $\mathrm{I}$ & Common & 90 & 60 & $\mathrm{AB}$ & $22 \pm 6$ \\
\hline 37 & Pinus massoniana & $\mathrm{I}$ & Common & 98 & 55 & $\mathrm{ABC}$ & $5 \pm 2$ \\
\hline 38 & Anthocephalus chinensis ${ }^{2}$ & II & Common & 92 & 52 & $\mathrm{AD}$ & $3 \pm 4$ \\
\hline 39 & Ormosia pinnata & $\mathrm{I}$ & Common & 94 & 51 & $\mathrm{AB}$ & $16 \pm 4$ \\
\hline 40 & Acacia crassicarpa & II & Common & 80 & 50 & $\mathrm{ABC}$ & $5 \pm 4$ \\
\hline 41 & Anthocephalus chinensis ${ }^{3}$ & II & Common & 92 & 35 & $\mathrm{AD}$ & $1 \pm 3$ \\
\hline 42 & Grevillea banksii var. forsteri & $\mathrm{I}$ & Common & 86 & 35 & $\mathrm{ABC}$ & $7 \pm 9$ \\
\hline 43 & Acacia podalyriifolia & II & Common & 90 & 33 & $\mathrm{ABC}$ & $4 \pm 2$ \\
\hline 44 & Acacia juncifolia & II & Common & 86 & 33 & $\mathrm{ABC}$ & $5 \pm 3$ \\
\hline 45 & Acacia adunca & II & Common & 86 & 26 & $\mathrm{AB}$ & $16 \pm 20$ \\
\hline 46 & Bauhinia purpurea & $\mathrm{I}$ & Common & 80 & 18 & $\mathrm{ABC}$ & $5 \pm 4$ \\
\hline 47 & Cassia bakeriana & $\mathrm{I}$ & Common & 90 & 24 & $\mathrm{AD}$ & $-89 \pm 20$ \\
\hline 48 & Rhodoleia championii & $\mathrm{I}$ & Common & 88 & 27 & $\mathrm{ABC}$ & $7 \pm 13$ \\
\hline 49 & Radermachera hainanensis & $\mathrm{I}$ & Rapid & 80 & 25 & $\mathrm{ABC}$ & $9 \pm 13$ \\
\hline 50 & Acacia decurrens & II & Common & 76 & 24 & $\mathrm{ABC}$ & $4 \pm 7$ \\
\hline 51 & Syzygium rehderianum & $\mathrm{I}$ & Common & 78 & 15 & $\mathrm{ABC}$ & $8 \pm 8$ \\
\hline 52 & Phoebe sheareri & $\mathrm{I}$ & Slow & 80 & 20 & $\mathrm{BC}$ & $3 \pm 6$ \\
\hline 53 & Pithecellobium clypearia & II & Common & 80 & 25 & $\mathrm{AD}$ & $-40 \pm 4$ \\
\hline 54 & Mytilaria laosensis ${ }^{1}$ & II & Rapid & 82 & 29 & $\mathrm{D}$ & $-200 \pm 13$ \\
\hline 55 & Mytilaria laosensis ${ }^{2}$ & II & Rapid & 78 & 26 & $\mathrm{D}$ & $-210 \pm 15$ \\
\hline 56 & Acacia mangium & II & Common & 82 & 22 & $\mathrm{ABC}$ & $-11 \pm 7$ \\
\hline 57 & Elaeocarpus apiculatus & $\mathrm{I}$ & Rapid & 78 & 18 & $\mathrm{ABC}$ & $-7 \pm 4$ \\
\hline 58 & Terminalia mantaly & $\mathrm{I}$ & Rapid & 76 & 16 & $\mathrm{ABC}$ & $-15 \pm 3$ \\
\hline 59 & Acacia falcata & I & Common & 50 & 12 & $\mathrm{BC}$ & $-32 \pm 5$ \\
\hline 60 & Zenia insignis & III & Rapid & 72 & 0 & $\mathrm{E}$ & - \\
\hline 61 & Castanopsis fissa & I & Common & 50 & 0 & $\mathrm{E}$ & - \\
\hline 62 & Magnoliaceae glanca & $\mathrm{I}$ & Rapid & 60 & 0 & $\mathrm{E}$ & - \\
\hline
\end{tabular}

${ }^{\mathrm{z}} \mathrm{SC}=$ seedling age class at time of test. $\mathrm{I}=\approx 15$ mo. old; $\mathrm{II}=\approx 8$ mo. old; $\mathrm{III}=\approx 3$ mo. old.

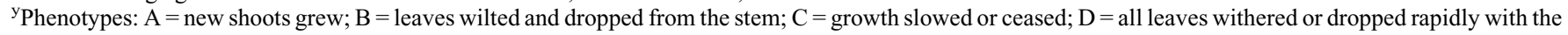
terminal bud remaining alive; $\mathrm{E}=$ the entire plant withered rapidly.

Superscript numbers $(1,2$, and 3$)$ after species name represent different provenances of same species.

$\mathrm{SGR}=$ seedling growth rate under natural conditions; FBGR = fresh biomass growth rate. 